\title{
FREDERIC L. PRYOR
}

\section{The Distribution of Nonagricultural Labor Incomes in Communist and Capitalist Nations}

In the economic literature one finds a plethora of propositions about the macroeconomic determinants of the distribution of labor incomes. One of the theories is that as the level of economic development rises, labor incomes are bound to become more equalized. Another view is that the larger the nation, the greater will be the separation of labor markets and the greater the inequality of labor income. Unfortunately there is relatively little speculation in the West about the impact of the economic system on the distribution of labor incomes, and those propositions that can be found are quite contradictory. Some have argued that labor incomes should become more equal under socialism because of the more equal distribution of education and because the government is able to reduce the power of noncompeting labor groups to raise their incomes far above those of the average workers. ${ }^{1}$ Others have suggested that the government's power to manipulate wages between industrial sectors and branches in order to attract workers to priority sectors could lead to greater inequalities in labor incomes. Since all of these arguments are based on what a socialist government "could" or "should" do, rather than what they actually are doing, their validity can be established only through empirical investigation.

The publication of data on the distribution of wages in various East European nations makes it possible to compare labor-income distributions in countries with different economic systems and to test a number of hypotheses about trends in the distribution of labor incomes with a much larger sample of countries; one early analysis of such data in Eastern Europe is the article by Walter Galenson and Alan Fox. ${ }^{2}$ The purpose of the present note is to

1. These ideas were suggested by Abram Bergson, The Structure of Soviet Wages (Cambridge, Mass., 1944), who then empirically showed size distributions of Soviet wages in the 1920 s and 1930s.

2. Walter Galenson and Alan Fox, "Earnings and Employment in Eastern Europe, 1957 to 1963," Quarterly Journal of Economics, 81 (May 1967): 220-40. Most of the literature about wages and salaries in socialist systems has focused on the Soviet Union

I would like to thank Janet Chapman, John Michael Montias, Howard Pack, Roland Pennock, Frank Pierson, Zora Pryor, and George Stolnitz for their helpful remarks on an earlier draft of this essay. Research was financed by the International Development Research Center of Indiana University. 
explore in a preliminary way some of the most important questions arising from these issues.

Empirical comparisons of the size distribution of labor incomes in different nations raise a number of difficult problems: comparable data are not readily available, measures of inequality vary considerably for the same population depending on the unit of analysis (individuals, "adult units," spending units, families), the measure of income (gross income, money income, disposable money income, or income adjusted by certain "budget standards" that take into account the family composition or the age or sex of the members of the unit under analysis), the time period covered, the regions and sectors of the economy covered, the inclusion or exclusion of certain groups (e.g., the unemployed, the part-time worker, apprentices, seasonal workers), and the method of sampling (which especially affects the upper and lower extremes of the distribution). ${ }^{3}$

Despite these difficulties, sufficient information is available to make a number of rough qualitative judgments about inequality of annual labor incomes outside of agriculture. To ease analysis, two major factors are separated below: labor-income differences in various branches of manufacturing and mining, and overall size distributions of nonagricultural labor incomes of fulltime male workers. Additional considerations are brought into the analysis in a qualitative manner. The final conclusion is that labor incomes in the nonagricultural sector are more evenly distributed in Eastern Europe than in Western Europe, other things remaining equal.

\section{Labor Earnings in Branches of Manufacturing and Mining}

Many Western observers of Eastern Europe have emphasized that although labor markets there are now relatively free of conscriptive devices, aggressive wage policies are followed by these nations to lure workers into certain designated priority branches; on the other hand, certain low-priority industries (especially in the consumer-goods branches) provide very low average wages. If this were true, then one might expect that the distribution of labor earnings among branches of manufacturing and mining would be much more unequal in the East than in the West. Fortunately, data are readily at hand to examine these matters empirically.

The first step is to compute and rank the average labor earnings in the various branches of manufacturing and mining that are defined in a relatively comparable manner. The average ranks for nations in the East and the West are presented in table 1. From these data several important generalizations can

alone. See, for example, Bergson, Structure of Soviet Wages, or Rudolf Becker, Sorejetische Lohnpolitik zwischen Ideologie und Wirtschaftsgesetz (West Berlin, 1965).

3. Quantitative estimates of the impact of these factors have been made by James N. Morgan et al., Incone and Welfare in the United States (New York, 1962), chap. 20. 
Table 1. Average Wages and Salaries of Workers and Employees

\begin{tabular}{|c|c|c|c|}
\hline \multirow{2}{*}{$\begin{array}{l}\text { ISIC } \\
\text { Number }\end{array}$} & \multirow[b]{2}{*}{ Industry } & \multicolumn{2}{|c|}{$\begin{array}{l}\text { Average Rank Order (from highest } \\
\text { average earnings to lowest) }\end{array}$} \\
\hline & & West, 1963 & East, 1963-66 \\
\hline 32 & Petroleum and coal products & 1 & 3 \\
\hline 34 & Primary metals & 2 & 2 \\
\hline 31 & Chemicals & 3 & 7 \\
\hline 38 & Transport equipment & 4 & 4 \\
\hline 36 & Machinery (except electrical, transport) & 5 & 5 \\
\hline $10-9$ & Mining & 6 & 1 \\
\hline 28 & Printing & 7 & 15 \\
\hline 27 & Paper products & 8 & 12 \\
\hline 37 & Electrical machinery & 9 & 6 \\
\hline 30 & Rubber products & 10 & 8 \\
\hline 21 & Beverages & 11 & 16.5 \\
\hline 35 & Metal products & 12 & 10 \\
\hline 33 & Stone, glass, clay products & 13 & 9 \\
\hline 39 & Miscellaneous industries & 14 & 11 \\
\hline 22 & Tobacco products & 15 & 18 \\
\hline 20 & Food processing & 16 & 16.5 \\
\hline 26 & Furniture & 17 & 14 \\
\hline 25 & Lumber products (except furniture) & 18 & 13 \\
\hline 29 & Leather products & 19 & 19 \\
\hline 23 & Textiles & 20 & 20 \\
\hline \multirow[t]{4}{*}{24} & Clothing & 21 & 21 \\
\hline & & West, 1963 & East, $1963-66$ \\
\hline & Number of countries in sample & 19 & 6 \\
\hline & $\begin{array}{l}\text { Coefficient of concordance (both statistically } \\
\text { significant at } 0.05 \text { level) }\end{array}$ & 0.59 & 0.80 \\
\hline
\end{tabular}

Note: Yugoslavia is omitted from the sample of East European nations, because its relative wage structure is much more similar to the pattern in the West. Sources and methods of calculation are presented in the statistical appendix.

be drawn. First, among the nations in both the West and the East, these rankings for the different countries are closely related to each other, with statistically significant concordance coefficients of 0.59 and 0.80 respectively. ${ }^{4}$ Second, the rankings of relative branch earnings for the two groups of nations are also significantly related to each other, with a Kendall rank order correlation coefficient of 0.67 . This similarity in the pattern of relative branch wages and salaries within and between the East and the West should not be surprising, since a distinct pattern of relative branch earnings in manufacturing and mining has been found by a number of economists, in both the time-series and the

4. The concordance coefficient is a measure of pattern of rank orderings and is analyzed by Maurice G. Kenda1l, Rank Correlation Methods, 3rd ed. (New York, 1962). When all of the rank orderings are the same, the concordance coefficient is 1.00 ; when the rank orderings form a completely random pattern, the coefficient is 0.00 . The greater similarity of wage structures in the East seems to be due to the deliberate imitation of the Soviet Union by the other nations. For an interesting study of this process in China see Peter Schran, "Unity and Diversity of Russian and Chinese Industrial Wage Policies," Journal of Asian Studies, 23 (February 1964) : 245-51. 
cross-section studies of Western nations. ${ }^{5}$ Third, the East European workers and employees receive relatively higher wages in mining, the lumber products industries, and the stone, glass, and clay products industries, and they receive lower wages in the printing, beverages, chemical, and paper industries. Except for mining, none of these relatively low- or high-wage industries are in priority or nonpriority branches of industry. For the remaining branches, average relative labor-income patterns are very similar. Although the East European nations may follow an aggressive wage policy regarding a few priority industries, such policies do not appear to distort greatly the pattern of relative wages.

The second step is to estimate the degree of dispersion of earnings among the branches of industry for each country and to compare them. Coefficients of variation (the standard deviation divided by the mean) were calculated for each nation on both an unweighted and weighted basis (using as weights the number of workers and employees in each branch), and then were compared by means of a regression analysis. The results ${ }^{b}$ for the unweighted regression are:

where

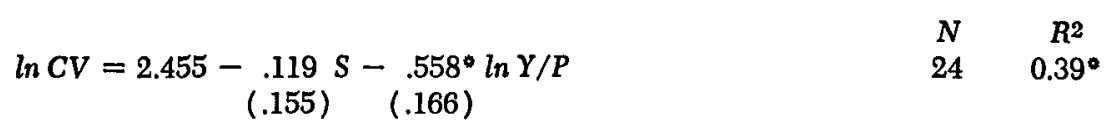

ln = natural logarithm,

$C V=$ coefficient of variation,

$S=$ economic system ( $=1$ if nation is Communist, $=0$ if capitalist),

$Y / P=$ income per capita (in dollars),

$N=$ number observed in sample,

$R^{2}=$ coefficient of determination,

- = statistically significant at the 0.05 level.

As one would expect, the degree of dispersion between average branch wages and salaries decreases as the level of development increases. More specifically, the coefficient of variation declines roughly 0.56 percent for each 1 percent increase in per capita GNP. Unlike the results of Galenson and Fox, which were based on a much smaller sample of Western nations, this study finds no significant differences between the Communist and the capitalist

5. See, for example, Walther G. Hoffman, Die branchenmässige Lohnstruktur der Industrie: Ein intertemporaler und internationaler Vergleich (Tübingen, 1961) ; United Nations, Economic Commission for Europe, Incomes in Postwar Europe (Geneva, 1967) ; John T. Dunlop and Melvin Rothbaum, "International Comparison of Wage Structures," International Labour Review, 71 (April 1955): 347-63; or D. E. Cullen, "The Interindustry Wage Structure, 1899-1950," American Economic Review, 46 (June 1956): 353-70.

6. Yugoslavia is omitted from the regression because of uncertainties regarding the handling of profit redistributions among the workers. The per capita GNP in dollars comes from series described by Frederic L. Pryor, Public Expenditures in Communist and Capitalist Nations (Homewood, Ill., 1968), appendix B-3. The results were roughly the same when either weighted or unweighted coefficients of variation were employed. Standard errors are placed under the coefficients. 
nations in the dispersion of wages and salaries among branches of industry when the level of development is held constant. We must therefore conclude that the "aggressive" nature of wage policies in Eastern Europe may have been overstated by East Europeans and overemphasized by Western analysts. Furthermore, we cannot expect differences in the dispersion of wages and salaries among the various branches of mining and manufacturing to affect significantly the relative degree of inequality of the size distribution of labor earnings in the East and West, at least in the mid-1960s for which the calculations were made. (In earlier times this might not have been true for the Soviet Union.)

\section{Size Distribution of the Wages and Salaries of Men}

We now come to the crucial question of how income is differentiated within particular industries. One aspect of this question is the degree to which "material incentives" are used to encourage production; another aspect is the degree to which particular groups (e.g., white- and blue-collar groups) act as noncompeting wage groups; and a final aspect is the degree of inequality of education (or human capital) among the labor force. For this human capital factor the evidence shows few important differences between nations with different economic systems, other things remaining equal. For the other considerations, however, we have little systematic evidence.

Until recently there were few empirical studies of the distribution of labor earnings in Eastern Europe, even though data are available for most countries. ${ }^{7}$ In order to take advantage of comparable data on the distribution of wages and salaries in Western Europe, I follow closely an analytical method pioneered by Harold Lydall. ${ }^{8}$ He plotted graphically the distribution of labor earnings and determined such earnings at particular percentiles (e.g., earnings in the fifth percentile are the earnings received by those whose labor incomes are greater than 95 percent of the rest of the labor force). He then calculated these earnings as a percentage of the median labor income (i.e., the wage received by those in the fiftieth percentile). This procedure enabled him to compare a great deal of available wage data without having to estimate the wages and salaries of those at the extremes of the distribution, which would be necessary if Gini coefficients of inequality were calculated. (In a Lorenz diagram the Gini coefficient is the ratio of the "area of inequality" to the total area under the diagonal.)

7. Aside from the pioneering study by Bergson, Structure of Soviet Wages, and a study by M. Gardner Clark of wages in the steel industry of a number of nations ("Comparative Wage Structure in the Steel Industry of the Soviet Union and Western Countries," I.R.R.A., Proceedings, 13 [December 1960]: 366-88), little empirical comparative work has been done until very recently.

8. Harold Lydall, The Structure of Earnings (Oxford: Clarendon Press, 1968). 
To achieve comparability, let us start with a "standard definition" of a specified group measured in a particular way. For simplicity, we follow Lydall and take the distribution of the pretax money wages and salaries of the men who worked, during the entire period under examination, in all nonagricultural occupations and industries for the whole country. Such data are available for some nations, but for others the published data are presented using different definitions, thus adjustments must be made. For certain countries wagedistribution data are available using a variety of definitions from which Lydall developed empirical norms to adjust variant wage distributions to the standard distribution. Although such a procedure for standardizing the data appears a bit informal, it seems adequate, for the degree of difference in these various definitions is not great.

For Eastern Europe particular problems arise in obtaining comparable data. First, the definitions used in calculating the wage distributions and the methods by which such distributions were calculated are often not as clearly specified as one might wish. Therefore, sometimes certain assumptions must be made, although they should not greatly affect the results. Second, the method by which the published data were adjusted to the "standard definition" was the informal procedure outlined above. Again, valid objections might be raised, but I doubt that the magnitudes involved in such adjustments allow significant bias to enter. It is only for the Soviet Union that significant errors might arise, and a detailed description of the methods used to make these estimates is presented in the appendix. ${ }^{9}$ Third, for certain East European nations we do not know whether bonuses have been included and whether particularly highly paid workers in the service sector were counted in. ${ }^{10}$ However, these omissions would mainly affect the degree to which those in the highest 5 percent of the wage distribution differ from the rest. Since I am really concerned with deviations from the median income of specific percentiles of workers or employees below this level, this should not greatly affect the results. Although caution must be exercised in interpreting the data, the experiment is, I believe, worth while. Relevant data are presented in table 2.

9. One other difficulty with the Soviet data must be mentioned. I chose 1959 , a year for which certain key wage-distribution data are available. But this year was in the middle of a ten-year period in which wage differentials were being considerably narrowed. Thus wage inequality in 1959 was considerably greater than in 1966, a fact that must be borne in mind in generalizing about inequality in Eastern Europe at present from the results in table 2.

10. Indeed, one reason why the distributions of labor earnings in Eastern Europe follow a log-normal rather than Pareto curve may be because such bonuses-which are given to the top labor-income receivers-are omitted. Additional doubts about the handling of bonuses are raised by Lydall's observation that relative incomes of white-collar workers compared with blue-collar workers in Eastern Europe are much lower (Structure of Earnings, pp. 150-51). 
Table 2. Distribution of Labor Earnings Following the

"Standard Definition" (in percentage)

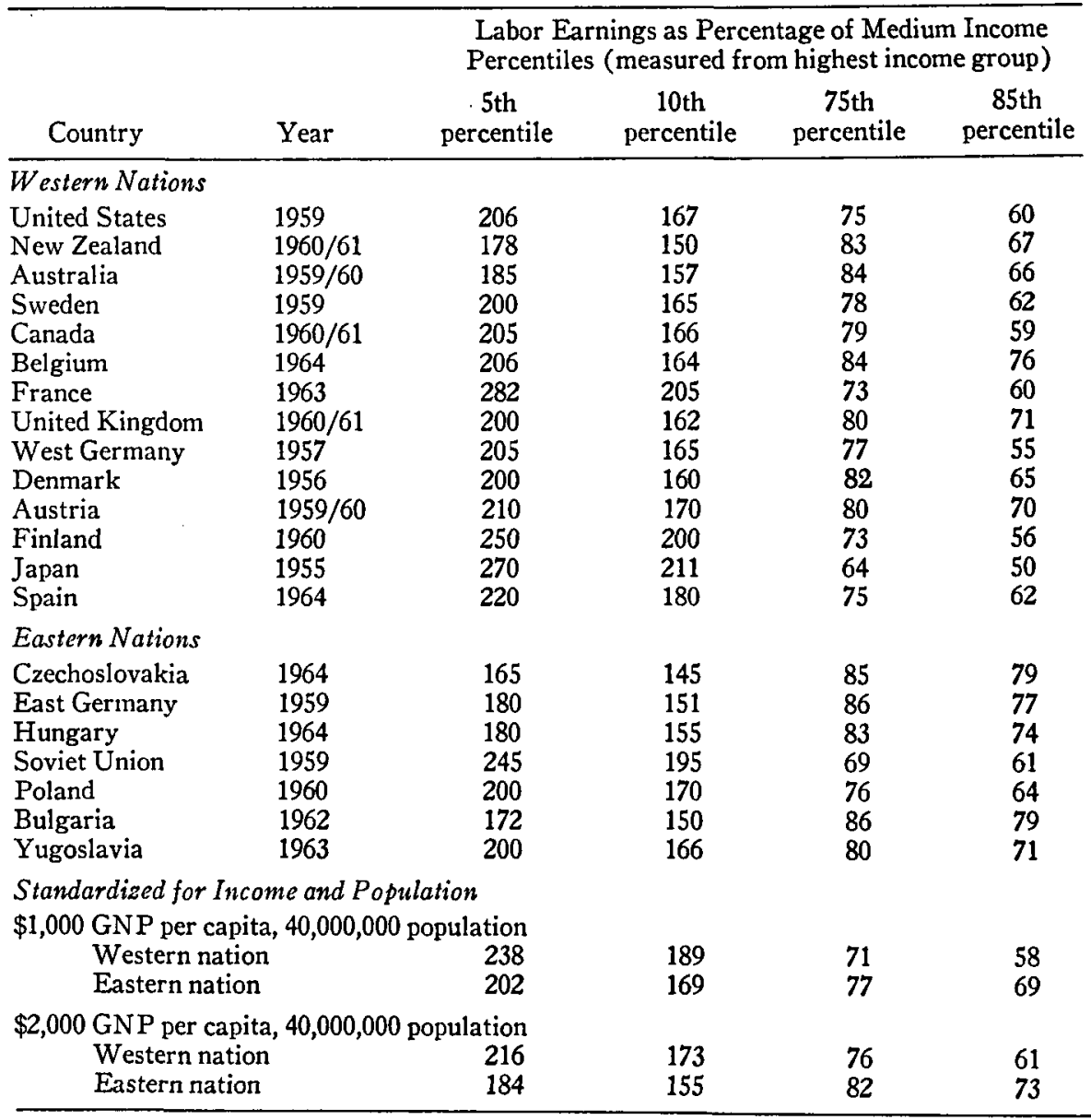

Note: The data in the first three columns for all countries except Bulgaria, East Germany, and the Soviet Union are from Lydall, Structure of Earnings, p. 153. For the last column, adjustments of data presented by Lydall in appendix 7 were made following the method he used to obtain the data in the first three columns. The undeveloped nations and the Netherlands (for which data were incomparable) were dropped from the analysis. For sources and estimation methods for Bulgaria, East Germany, and the Soviet Union see the statistical appendix. The data available for Rumania (see statistical appendix) are in the same order of magnitude as the data for the other East European nations. The data for the "standardized" nations in East and West were obtained from a regression analysis explained in the text. The exact equations are presented in the statistical appendix. Countries are arranged according to declining per capita GNP weighted by dollar prices.

In order to draw certain general conclusions from the data-especially regarding the influence of the economic system-it is useful to separate out the most important causal factors. For example, it has often been claimed that labor incomes become more equal as the level of development rises. As sup- 
porting evidence a number of institutional and economic factors can be mentioned: when a nation's level of development rises, a larger percentage of the population receives primary, secondary, and higher education, thus the distribution of education, and incomes arising from education, become more equal; furthermore, as it becomes less expensive to transmit labor-market information, labor mobility increases, wage differentials in various markets may diminish, and barriers around noncompeting groups become less important.

The size of a nation, as measured by the population, might influence laborearning differentials in two ways. First, as I noted above, the larger the population, the greater the number of regional labor markets and the greater the likelihood of a wide range of wages for the same kind of work. Second, as I have discovered, the larger the population (or total GNP), the higher the percentage of the labor force working for a small number of large enterprises. This might introduce a "standardization effect" that would narrow the differentials between regions and counteract the first factor. (It must be added that this "standardization effect" might be a product of the economic system when wages are determined centrally, rather than a result of the supply and demand forces in each region.)

Using a regression analysis we can investigate the influence of per capita income, total population, economic system, and other variables on the wagedifferential data in table $2 .{ }^{11}$ It turns out that the first three variables appear to play a statistically significant explanatory role, and other variables that were tested seem less important. Several important conclusions can be drawn. First, as expected, the degree of inequality of nonagricultural labor earnings declines as the level of development rises. Second, the degree of labor-income inequality increases with the size of the population of a nation. Thus the regional separation of labor markets appears to swamp the "standardization effect" discussed above. Third, the degree of inequality of labor incomes is greater in the West than in the East, other things being equal. If we calculate Gini coefficients of inequality, we find that the coefficients in the Eastern nations are about 0.06 percent greater than in the Western nations. ${ }^{12}$ There is some evidence that this

11. The regression equations for the pooled sample are given in the statistical appendix. Tests were carried out to see whether it was statistically legitimate to pool the data from the East and the West, and in each case it was. The regressions are calculated in logarithms in order to minimize the influence of extreme points; other forms of the regression were also calculated and, surprisingly, showed roughly the same results. Other variables were also added to the regressions, such as growth of GNP, but these did not prove statistically significant determinants. (It can be argued that the demand for skilled workers in preference to unskilled workers changes if the economy is expanding rapidly and that this would affect wage differentials, other things being equal.)

12. The Gini coefficients were calculated in two steps. First, wage differentials for two other percentiles (the twentieth and the ninety-fifth) were estimated, and regressions similar to those discussed in note 11 were calculated. Second, I assumed that for nations 
greater equalization of income in the East may be due to a lower ratio between the average earnings of white-collar and blue-collar workers. ${ }^{13}$ Unfortunately we know too little about wages and salaries in Eastern Europe to know if other causal factors play an important role in these matters.

The Soviet Union appears to have the greatest inequality of labor income of any nation in the sample (although this inequality undoubtedly decreased considerably by 1966). Given the size and relatively underdeveloped state of the Soviet economy compared with such nations as Czechoslovakia and Sweden, one would expect greater inequality. Without holding such factors constant in any comparison of labor-income equality between two nations, very misleading results can be obtained.

\section{Other Factors}

We cannot, of course, generalize quantitatively about the distribution of labor incomes of families from data on the distribution of individual labor incomes without additional information about unemployment, earning differentials between men and women, degree of moonlighting, extent to which families whose head earns a particular income have two or more wage earners, correlation between the level of wages of household heads and other working members of the family, and so forth. Nevertheless, certain qualitative judgments are relevant.

In Eastern Europe the participation rate of women in the labor force is higher than in the West, especially among women with small children (because of the extensive network of day-care centers). This difference probably contributes to making the distribution of family incomes in relation to individual labor earnings somewhat more equal in the East than the West. The other factors mentioned in the preceding paragraph should be considerably less important in East-West comparisons, since they are much less specifically related to the economic system.

\section{Conclusions}

Other things being equal, nonagricultural labor incomes are more evenly distributed in the East European nations than in the West. The ceteris paribus clause includes a number of factors for which we have little data but which probably do not greatly affect the major conclusion. ${ }^{14}$ To what can this differ-

in both the East and the West the average labor earnings of all workers above the fifth percentile were 16.7 percent higher than the labor earnings of those in the fifth percentile, and that the average earnings of all those below the ninety-fifth percentile were 10 percent below the earnings of those in the ninety-fifth percentile.

13. Lydall, Structure of Earnings, pp. 150-51.

14. My results are qualitatively consistent with the scattered data on income distribu- 
ence be attributed? First, in the comparison of average wages and salaries in individual branches of mining and manufacturing, no differences between nations with different economic systems could be found, other than those due to level of development. This branch factor, therefore, is not responsible for the differences in distribution of labor earnings. Second, the similarity of enrollment rates in primary and secondary schools in Communist and capitalist nations rules out level of education as an explanatory variable. ${ }^{15}$ Third, although some evidence is available that differences in white- and blue-collar labor incomes are smaller in Eastern Europe than in the West, relatively little is known about this, and therefore no definite conclusion can be drawn. I strongly suspect that attempts of centralized economic-policy organizations to standardize wages play an important role-that is, that differences in the size distribution of labor incomes outside of agriculture may be attributed partly to conscious efforts in Eastern Europe to set up standard wage categories. Furthermore, incentives established for managers have, until very recent years, encouraged the "hoarding" of labor, even though many of the personnel acquired are not especially capable or productive; and it may be difficult to lure highly productive workers away from a given plant by means of higher wage payments because of the difficulties in rehousing them.

It is hoped that the increasingly detailed economic data released by the East European nations will soon provide enough clues so that these questions can be more thoroughly examined.

\section{STATISTICAL APPENDIX}

\section{A. Sources and Comments for the Data in Table 1}

The data for the Western nations are from United Nations, The Groveth of World Industry, 1953-65: National Tables (New York, 1967), and were obtained by dividing the total wages and salaries by the number of workers and employees. For some nations the years on either side of 1963 were used. The industry breakdown followed the two-digit International Standard Industrial Classification (ISIC) for manufacturing (20 through 39 ), but for mining all industries were lumped together. For the East European nations I attempted to obtain comparable data which could be arranged according to the ISIC classification. For some countries, however, this did not prove feasible, and somewhat incomparable data had to be employed. The following sources were used.

For Bulgaria the data are from Tsentralno statistichesko upravlenie, Statisti-

tion in the various East European nations (discussed in United Nations, Incomes in Postwar Europe, or presented in the various national statistical yearbooks of these nations), which I have not used in these comparisons because the manner in which they were calculated is not specified and because they may be considerably less comparable with the Western data than the wage information.

15. Pryor, Public Expenditures, chap. 4. 
cheski godishnik na Narodna republika Bülgariia, 1967 (Sofia, 1967), and cover state industries only for 1965 .

For Czechoslovakia the data are from Státní statistický úrad, Statistická ročenka Československé socialistické republiky, 1966 (Prague, 1966), and cover only blue-collar workers in 1965.

For East Germany the data are from Staatliche Zentralverwaltung für Statistik, Statistisches Jahrbuch der Deutschen Demokratischen Republik, 1967 (East Berlin, 1967 ), and cover workers and employees only in the state and cooperative sectors in 1965.

For Hungary the data are from United Nations, Growth of World Industry, and are for 1964.

For Poland the data are from Główny urząd statystyczny, Statystyka przemyslu, 1958, Statystyka Polski, no. 41 (Warsaw, 1960).

For the Soviet Union the data are from Vladimir G. Treml, The 1959 Soviet Intersectoral Flow Table (Washington, D.C.: Research Analysis Corporation Technical Paper RAC-TP-137, November 1964), supplemented by several additional sources. The results are similar to those reported by Norman Kaplan, Earnings Distributions in the USSR (Santa Monica: Rand Corporation Memorandum RM-6170, November 1969).

For Yugoslavia the data are from Savezni zavod za statistiku, Statistički bilten, no. 421 (Belgrade, 1966).

\section{B. Sources and Comments for the Data in Table 2}

The data for Australia, Austria, Belgium, Canada, Czechoslovakia, Denmark, Finland, France, West Germany, Hungary, Japan, New Zealand, Poland, Spain, Sweden, the United Kingdom, the United States, and Yugoslavia come from Harold Lydall, The Structure of Earnings (Oxford: Clarendon Press, 1968). I omitted the Netherlands because of certain incomparabilities. For Hungary I recalculated the estimates, using somewhat different data, and obtained almost exactly the same results.

The data for the Soviet Union were estimated in a simpler manner. Data on the wages of blue-collar workers in manufacturing are presented in graph form by M. Mozhina, "Izmeneniia v raspredelenii promyshlennykh rabochikh SSSR po razmoram zarabotnoi platy," Biulleten' nauchnei informatsii: Trud $i$ zarabotnaia plata, 1961 , no. 10, pp. 18-25. I took readings on this graph, plotted a cumulative wage curve (using log-probability paper), and obtained almost the same decile and quartile ratios as Mozhina presents. (My thanks to Janet Chapman for sending me a copy of this article.) In another Soviet source (N. M. Rimashevskaia, Ekonomicheskoi analiz dokhodov rabochikh i sluzhashchikh, Moscow, 1965, p. 43) we are told that the ratio of wages and salaries for men and women in the entire economy at the ninetieth and tenth deciles is $4: 2$. Compared with labor-income differentials using Lydall's standard definition, the Mozhina data understate the differentials by excluding salaries and also earnings in nonmanufacturing sectors, and the Rimashevskaia datum overstates the differentials by including the earnings of women and also the wages and salaries in the farm sector (i.e., state farms). I estimated the labor-income distribution for the Soviet Union by adjusting the Mozhina curve with the Rimashevskaia datum. After the decile readings were obtained, further 
adjustments were carried out so that the bias due to a more inclusive coverage was eliminated, using Lydall's adjustment procedures.

Data for wages and salaries of all employed workers and employees for Bulgaria come from Tsentralno statistichesko upravlenie, Statisticheski godishnik, 1967; and for East Germany from United Nations, Economic Commission for Europe, Incomes in Postwar Europe (Geneva, 1967), chap. 9, p. 23. Both sources contain a bias for greater dispersion than Lydall's "standard definition," because they include the wages and salaries of women and workers on state farms; therefore, they were adjusted accordingly.

Certain scattered data are also available for Rumania, but they contain too many uncertainties to allow their use in the table.

\section{Regressions}

Aside from the regressions underlying the "standardized" data in table 2, I also include a set of regressions with the size variable omitted. Standard errors are placed under the coefficients in the following regression formulas for nonagricultural labor-income data:

where

$$
\begin{aligned}
& \ln X_{5}=5.811+\underset{(.019)}{.057^{\circ}} \ln P-\underset{(.050)}{.163^{\circ} \mathrm{S}-\underset{(.058)}{.137^{\circ}} \ln Y / P} \quad \begin{array}{ccc}
N & R^{2} \\
0.55^{\circ}
\end{array} \\
& \ln X_{10}=5.665+.042^{\circ} \ln P-.108^{\circ} \mathrm{S}-.126^{\circ} \ln Y / P \quad 21 \quad 0.56^{\circ} \\
& \begin{array}{lll}
(.014) \quad(.037) \quad(.043)
\end{array} \\
& \ln X_{75}=4.138-.041 \ln P+.068^{\circ} \mathrm{S}+.083^{\circ} \ln Y / P \quad 21 \quad 0.67^{\circ} \\
& \text { (.009) (.023) (.027) }
\end{aligned}
$$

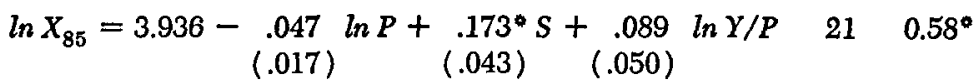

$$
\begin{aligned}
& \ln X_{\overline{5}}=6.403-.153^{\circ} \mathrm{S}-.141^{\circ} \ln Y / P \quad 21 \quad 0.32^{\circ} \\
& \ln X_{10}=6.101-.100^{\circ} \mathrm{S}-.130^{\circ} \ln Y / P \quad 21 \quad 0.33^{\circ} \\
& \text { (.044) (.051) } \\
& \ln X_{75}=3.717+\underset{(.033)}{.061} S+\underset{(.039)}{.086^{\circ}} \ln Y / P \quad 21 \quad 0.26^{\circ} \\
& \ln X_{85}=3.449+.164^{\circ} \mathrm{S}+.093 \ln Y / P \quad 210.38^{\circ}
\end{aligned}
$$

ln = natural logarithm,

$X_{p}=$ wages and salaries in a specified percentile $(p)$ in a cumulated labor earning frequency curve (as a percentage of median wage and salary),

$S=$ economic system ( $=1$ if nation is Communist, $=0$ if capitalist),

$P \quad=$ population (in 1,000 people),

$Y / P=$ income per capita (in dollars),

$N=$ number observed in sample,

$R^{2}=$ coefficient of determination,

- = statistically significant at the 0.05 level. 